УДК.811.161.2’373

Г. П. Клімчук

\title{
ЛЕКСИКА ЛАТИНСЬКОГО ПОХОДЖЕННЯ В ПУБЛІЦИСТИЦІ М. ГРУШЕВСЬКОГО
}

Клімчук Г. П. Лексика латинського походження в публіцистиці М. Грушевського.

Статтю присвячено дослідженню лексичних запозичень латинського походження в публіцистичній спадщині М. Грушевського; здійснено аналіз семантичного складу й функціональних особливостей латинізмів, з'ясовано їх стилістичний статус у сучасній літературній мові.

Ключові слова: запозичення, латинізм, термін, детермінологізація, західноукраїнська мовно-літературна традиція, мовна норма.

Климчук Г. П. Лексика латинского происхождения в публицистике М. Грушевского.

Статья посвящена исследованию лексических заимствований латинского происхождения в публицистическом наследии М. Грушевского; осуществлен анализ семантического состава и функциональных особенностей латинизмов, определен их стилистический статус в современном литературном языке.

Ключевые слова: заимствование, латинизм, термин, детерминологизация, западноукраинская традиция литературного языка, языковая норма.

Klimchuk G. P. Vocabulary from Latina in the publicistic of M. Hrushevsky.

The article is devoted to investigation of lexical borrowings from Latina in the publicistic of M. Hrushevsky; the analysis of semantic composition and functional features of latinisms are made there, their stylistic status in the modern literary language is also determined in the article.

Key words: borrowing, latinism, term, determinologisation, western Ukrainian literary language tradition, substandard.

Розвиток української літературної мови впродовж майже цілого XX ст. мав директивний характер i нерідко відзначався насильницьким утручанням у ї живий організм, а тому після відмови від тоталітарної ідеології вектор уваги лінгвістів дедалі частіше зорієнтований на повернення мови до іiі першоджерел. Особливої актуальності в цьому аспекті набувають дослідження питань функціонування й соціальної репрезентації української мови в один із найбільш продуктивних відтинків iii розвитку - кінець XIX та початок XX ст. Окреслений хронологічний етап увійшов в історію мови передусім як період становлення іiі стилістичної системи, формування літературних канонів, напруженої лексикографічної практики й інтенсивної мовотворчої діяльності соціально, політично та лінгвістично активних персоналій, що виступили своєрідними нормалізаторами і каталізаторами тогочасної української мови. Чільне місце в когорті таких мовних особистостей посідає відомий репрезентант українського національно-культурного відродження початку XX ст. М. Грушевський, лінгвістичні погляди й мовотворчі настанови якого в 
офіційному радянському мовознавстві піддавалися нищівній критиці і спотвореній інтерпретації.

У новітньому лінгвістичному дискурсі вийшло 3 друку чимало історичних, мовно-культурологічних і власне мовознавчих праць, у яких розглянуто рефлексії М. Грушевського щодо практичних питань функціонування української мови й завдань ії утвердження в суспільстві (М. Алексієвець， М. Жулинський， П. Ковалів， А. Мамалига， Л. Мацько, Л. Полюга), роль визначного діяча в розбудові наукового стилю української мови і ключові положення його лінгвістичної концепції (Я. Дашкевич, Г. Мацюк, Т. Панько, Т. Розумик, М. Сюсько), позицію в літературно-наукових дискусіях початку XX ст. (Р. Трифонов, Б. Сокіл) та значення у становленні українського правопису (О. Гузар). Проте, незважаючи на такий посилений інтерес до мовного аспекту діяльності науковця, сучасній україністиці все ще вкрай бракує спеціальних, підкріплених текстовою базою, студій його мовостилю, на що повсякчас указують фахівці з історії мови. Це зумовлює перспективність розробки мовної манери М. Грушевського, зокрема - у царині публіцистики.

Мета нашої статті полягає в дослідженні структурно-семантичних i функціонально-стилістичних особливостей лексики латинського походження в суспільно-політичних дописах ученого.

Зауважимо, що в науковій літературі під «латинізмами» традиційно розуміють слова, їх окремі значення, вислови, морфеми тощо, запозичені $з$ латинської мови або утворені за їх зразком [14, с. 292], однак у пропонованій розвідці цим терміном послуговуємося насамперед для номінації власне лексичних запозичень, прямо чи опосередковано перенесених на український мовний грунт із латинської мови.

Лексика латинської етимології - одна 3 найпродуктивніших стилеутворювальних складових публіцистичної практики М. Грушевського. Кількісно найбільш представленими є латинськомовні одиниці, що в кінці XIX - на початку XX ст. обслуговували західноукраїнський варіант літературної мови $\mathrm{i}$ становили спільний лексичний фонд української, польської та почасти німецької мов. Аналізуючи чужоземні засоби в періодичній пресі зазначеного періоду, М. Жовтобрюх кваліфікує відповідні слова як соціально зумовлені західноукраїнські локалізми, що не ввійшли «до лексичного складу місцевих українських говорів, а належали до професійного словника певних кіл інтелігенції» [6, с. 152]. Із семантичного погляду це передусім запозичення для відображення необхідних на той час абстрактних понять, що об'єднані спільним частиномовним значенням предметності й охоплюють такий тематичний спектр:

І. Лексика на означення понять зі сфери суспільно-політичного жсиття. Назване тематичне (лексико-семантичне) поле характеризується 
найвищою відтворюваністю. У його межах сегментуємо кілька лексикосемантичних груп:

a)номени на означення понять внутрішньої і зовнішньої політики : денунціація - донос [3, с. 144]; інгеренція втручання [4, с. 83]; пертрактації - переговори [4, с. 491]; пресія пригноблення, утиски [2, с. 146]; репріманда - догана, докір, нагінка [3, с. 236]; рескрипm - акт монарха у формі конкретного наказу міністрові чи якомусь іншому урядовцеві [2, с. 167] тощо. Наприклад: $B$ останніх енунціаціях з польської сторони се було піднесено досить виразно, а не треба було й таких заяв, щуоби знати наскільки се важно з становища польської політики, в Галичині спеціально [4, с. 58], де енунціація «урядова заява» (пор.: енунціяція, лат. - заява, зложена правительственим заступником [10, с. 117]; пол. епиnсјасја, книжн. - заява, декларація); Се була, позволю собі назвати, перша сецесія вищих верств українськоруського народу [2, с. 113], де сецесія - «відступництво» (пор.: сецесія, лат. - 1) відокремлення; 2) відступництво [1, с. 389]; пол. secesja 1) відокремлення; 2) мистецький стиль; нім. die Sezession - відокремлення, відділення). Проілюстровані терміни виявляють значну частотність у науково-популярних i критичних статтях, присвячених важливим міжнародним чи власне національним подіям. Позаяк окреслені публікації адресовані передусім інтелігенції, що вміло оперувала відповідними поняттями, переважна більшість цих чужомовних елементів уводиться автором у структуру творів без пояснення їхнього семантичного обсягу;

б) номени на означення понять виборчих реалій i парламентаризму. Названий різновид латинськомовних запозичень загалом репрезентований терміноодиницями, які належать до фонду інтернаціональної лексики: абдикація - зречення, вихід 3 певної політичної сили [2, с. 137]; абсентеӥзм - ухиляння виборців від участі у виборах до державних органів влади [3, с. 169]; касація (виборів) визнання виборів недійсними [2, с. 351]; обструкція - дія, демонстративно спрямована на зрив парламентарного засідання за допомогою гамору, виголошення довгих, непотрібних промов [3, с. 115]. Наприклад: Дума потребує здержати їх (засуди смерті - Г. К.) своїми інтерпеляціями людей розстрілюють далі [2, с. 137], де інтерпеляція - «публічне звернення представників парламенту до міністра або уряду стосовно загального напрямку політики чи важливих державних справ» (пор.: інтерпеляція, лат. - запитання до міністра чи уряду від окремих представників політичних партій, поставлене в парляменті в якій-небудь важливій справі чи про загальний напрямок політики [1, с. 182]); Чому ж ви боїтеся дати самому народові се заявити? Чому до дрожчів приводить вас саме слово плебісцит? [3, с. 461], де плебісцит - «референдум» (пор.: плебісцит, лат. - усенародне обговорення, голосування [11, с. 742]; 
плебісцит - усенародне голосування з найважливіших питань державного життя; референдум [12, VI, с. 573]).

Специфіка окресленої тематичної групи полягає в тому, що належні до неї латинізми виявляють здатність виходити за межі власного термінологічного поля й модифікувати притаманний їм лексичний уміст. Так, скажімо, один із наведених вище текстових фрагментів демонструє характерне для української літературної мови кінця XIX - початку XX ст. функціонування іменника інтерпеляція 3 термінологічним значенням «публічне звернення представників парламенту до міністра або уряду стосовно загального напрямку політики чи важливих державних справ», однак подекуди натрапляємо на розширення семантики цієї лексеми й використання ii $з$ більш узагальненим значенням «запит», наприклад: Hарешті третє - се оповідання «Муха»в І кн. «Вістника» за сей рік, за котре о. Ю. Дуткевич ставив інтерпеляцію на загальних зборах Товариства ім. Шевченка, називаючи се оповідання неморальним [2, с. 155]. Припускаємо, що засвідчена у проілюстрованій мовленнєвій ситуації семантична модифікація терміна інтерпеляція спричинена впливом польської мови, у якій названий латинізм і сьогодні побутує 3 тотожним лексичним наповненням (пор.: пол. interpelacja - запит; interpelacja sejmowa - запит у сеймі). «Словник української мови» (далі - СУМ) не відображає змін у семантичній структурі аналізованої лінгвоодиниці й відбиває лише iii термінологічну специфіку, до того ж у властивій для радянської ідеології інтерпретації (пор.: інтерпеляція, політ. - у буржуазних країнах - звернення депутата парламенту до уряду або його представника 3 певним питанням, після обговорення якого приймається відповідна ухвала [12, IV, с. 39]);

в) номени на означення понять із царини адміністративного урядування та громадського життя соціуму. Латинізми окресленої лексико-семантичної групи 3 погляду сучасних літературних норм відійшли до категорії застарілих і перебувають у пасивному словнику української мови: Під впливом сеї опінії робиться моральна пресія навіть $і$ на більи байдужих членів духовної верстви... [2, с. 146], де опінія - «громадська думка» (пор.: опінія, лат. - думка загалу про когось або про якийсь вчинок [1, с. 521]; опінія, заст. - громадська думка [12, V, с. 713]; пол. оріnia - 1) думка, погляд; 2) оцінка); Центральне правительство виявило певну свою безсильність перед краєвим, перед галицьким намісником та ще й таким потентатом, обдарованим необмеженим довір'ям изісаря, як покійний граф Потоизький [3, с. 267], де потентат - «можновладець, магнат» (пор.: nomeнтат, лат. можновладця, володар, магнат [1, с. 341]; потентаm, заст. - володар [12, VII, с. 402]; пол. potentat - можновладець, багатій, магнат). Наявність тотожних відповідників у польській мові дає підстави говорити про 
посередництво останньої в позичанні цих словесних засобів українською лексичною системою.

ІІ.Лексика на означення понять із царини освіти, науки, медицини. Викладацька i наукова діяльність М.Грушевського у Львівському університеті, що на той час фактично перебував у володінні поляків, створювала умови для безпосереднього контактування вченого 3 польською професурою. Це спричинило проникнення в мовотворчість останнього низки типових для польського освітньо-наукового дискурсу педагогічних термінів, які етимологічно пов'язані 3 латинською мовою. Такі одиниці трактуємо як латинізми, запозичені в українську мову за посередництвом польської. Загалом згадані лексичні засоби належать до часто відтворюваних у львівський період публіцистичної діяльності М. Грушевського, де представлені такими лексико-семантичними групами:

a) номени, що обслуговували наукову та викладацьку діяльність осіб у середніх і вищих навчальних закладах : колоквіум - наукові збори, під час яких проводиться обговорення доповідей на визначену тематику [2, с. 179]; конвікm - навчально-виховний заклад для молоді; пансіонат [2, с. 151]; утраквізм, утраквізація - двомовне викладання в навчальних закладах [4, с. 17]; фреквенція - відвідуваність (школи, наукових товариств, учительських семінарій) [4, с. 84]. Наприклад: Габілітація вимагає дуже солідного наукового приготовлення; як я вже казав, тутешню габілітацію можна щзодо вимог прирівняти більи-мени зі степенем магістра російських університетів [2, с. 186], де габілітація «право викладання в університеті» (пор.: габілітація, лат. університетський іспит, що управнює викладати на університеті [10, с. 62]; габілімація, зах. - складання іспиту, що дає право викладати в університеті [12, II, c. 8]; пол. gabilitacja - прилюдний захист дисертації); Аби бути прийнятим в студенти Львівського (як $і$ всякого іншого австрійського) університету, треба мати «матуру»-свідочтво зрілості [3, с. 482], де матура - «свідоцтво зрілості» (пор.: матура, лат. - останній іспит при закінченні гімназіі, що давав право перейти до університету [1, с. 252]; матура - «2. n. лат.; на В. У. - іспит зрілості» [8, с. 224]; матура, зах. - у гімназії - іспити на атестат зрілості [12, IV, с. 635]; пол. matura - 1) іспит на атестат зрілості; 2) свідоцтво про закінчення навчального закладу). Наведені текстові фрагменти переконують, що основне функціональне призначення окресленої категорії латинськомовних запозичень у суспільно-політичних дописах М.Грушевського полягало в тому, аби репрезентувати наддніпрянським реципієнтам конкретні реалії галицького освітньонаукового життя. У статтях київської доби такі латинізми зазвичай супроводжуються специфічним способом їх графічної передачі написанням у лапках;

б) номени на означення осіб за їх професійною діяльністю, найменування університетських наукових 
посад і з вань: доцент - учене звання і посада викладачів університету [2, с. 179]; суплент - помічник викладача, особа без габілітації [2, с. 179]; суплентура - заступництво викладача [4, с. 22]. Наприклад: По трьох роках організуються периі катедри - наприклад, три катедри $і$ три посади ад'юнктів; кожного року потім прибуває ще по парі... [3, с. 351], де ад’юнкт - «молодший науковий співробітник» (пор.: адьюнкт, лат. 1) помічник професора або й молодший урядовець на Заході; 2) помічник пастора в євангелитській церкві [1, с. 13]; пол. adjjunkt - 1) помічник посадової особи; 2) молодший науковий співробітник); Прелегент мав на меті подати загальний огляд польсько-українських конфліктів від Люблінської унії аж до кіния XVII в... [2, с. 249], де прелегент - «лектор» (пор.: прелегент, лат. - той, хто читає реферат, доповідь, лектор [1, с. 523]; пол. prelegent - лектор, доповідач);

в) номени на означення вузькоспеціалізованих наукових понять різних галузей знань. Найвищу продуктивність у складі відповідної групи запозичень із латинської мови виявляють репрезентанти медичної терміносистеми. Спостереження за семантичними характеристиками цих слів засвідчують кількісну перевагу медичної лексики, яка використовується адресантом 3 образним, переносним значенням. Проникаючи у структуру політичних текстів, такі мовні засоби розширюють притаманні їм синтагматичні зв'язки, утрачають термінологічну семантику i, метафоризуючись, набувають ознак загальновживаної лексики. Наприклад: Прихильники $i$ друзі Галичини - се були прихильники України будочої, відродженої, оновленої, видвигненої $з$ вікового розпаду $i$ атрофії [3, с. 119], де атрофія, перен. - «занепад, деградація» (пор.: атрофія, лат - 1) біол., мед. прижиттєве зменшення розмірів органа або тканини в організмі тварин і людини; 2) перен. притуплення, утрата якого-небудь чуття, властивості [11, с. 133]); Icmopiя минувшого століття оправдовує сей молодечий запал, сі надї, які покладаємо на енергію національного організму-реконвалесцента, з якою він поновлює понесені страти [2, с. 208], де реконвалесцент, перен. «нація, що перебуває на стадії відродження» (пор.: реконвалесценція, лат. видужування, виздоровлювання [1, с. 524]; реконвалесцент, мед. - людина, яка ще не одужала остаточно, але вже не має яскраво виявлених клінічних ознак хвороби [12, VIII, с. 495]). Як видно з комунікативних ситуацій, автор переосмислює зміст спеціальної медичної термінологї й послуговується нею як засобом вторинної номінації конкретних явищ чи реалій національного життя. Образне ототожнення українського народу з хворим організмом людини, очевидно, пояснюється основними положеннями історіософської концепції М.Грушевського, згідно 3 якою суб'єктом культурно-історичного поступу $\epsilon$ «нарід» - «жива національна індивідуальність», що пов'язана в єдине ціле антропологічними, психофізичними i культурними прикметами. Проводячи паралелі між 
важливими подіями й реаліями суспільної дійсності та біологічними процесами, що протікають у людському організмі, учений зосереджує увагу читачів на яскравих художніх метафорах, завдяки чому забезпечує адекватність i ефективність сприйняття концептуальної змістової інформації.

Предметом посиленої уваги з-поміж вузькоспеціалізованих наукових термінів слугують латинськомовні лексичні компоненти, що на зламі XIX $\mathrm{XX}$ ст. репрезентували царину лінгвістики. Окремі 3 них збережені українською мовознавчою практикою й надалі продовжують функціонувати як власне філологічні терміни, напр.: сентенція - короткий влучний вислів морально-повчального змісту [4, с. 53]; вокабула - окреме слово як предмет лексикології чи лексикографії [3, с. 244], однак особливе наукове зацікавлення викликають латинізми, які на сучасному хронологічному зрізі зазнали семантичного переосмислення й утратили притаманну їм лінгвістичну спеціалізацію. Так, скажімо, в аналізованих науковопопулярних дописах термінологічні одиниці деклінація й кон'югація вживаються зі значеннями «відмінювання частин мови» та «дієвідміна», наприклад: По огляді українських суфіксів іменникових, прикметникових, прислівникових $i$ дієслівних перейшов (прелегент - Г.К.) до огляду деклінації. <..> Те ж саме зроблено $і$ при огляді кон'югації [2, с. 255]. Аналогічні лінгвістичні характеристики ці чужомовні компоненти виявляють і в нинішньому німецькому узусі, де побутують як терміни граматики (пор.: нім. die Deklination - грам. відміна, die Konjugation - грам. дієвідміна). Натомість сучасні українські лексикографічні розвідки демонструють міграцію окреслених словесних засобів до складу інших терміносистем (пор.: деклінація, лат. - 1) магнітне схилення, відхилення магнітної стрілки компаса від географічного меридіана; 2) заст. відмінювання частин мови; відміна $[11$, с. 330]; кон'югація, лат. - 1) тип статевого процесу, що полягає в злитті двох особин, які при цьому обмінюються частинами свого ядерного апарату і цитоплазмою; 2) попарне тимчасове зближення гомологічних хромосом, під час якого вони обмінюються гомологічними ділянками [11, с. 557]). Можна припустити, що вилучення з мовознавчого обігу латинізмів деклінація й кон'югація відбулося після створення на українському грунті власних вербальних знаків для відображення відповідних лінгвістичних реалій, адже, як відомо, проблема вироблення наукової термінології на етнографічних засадах у кінці XIX початку XX ст. не була остаточно розв'язана, а тому мовцям, зокрема й М. Грушевському, для номінації зазначених лінгвістичних понять доводилося вдаватися до класичного «плану вираження».

III. Лексика на означення загальнонаукових та абстрактних nонять. Чимало репрезентантів цього тематичного поля мали в українській мові кінця XIX - початку XX ст. автохтонні відповідники, однак М. Грушевський свідомо уникав їх, надаючи перевагу книжним лексемам 
латинського походження. Цілком очевидно, що подібна манера автора була продиктована прагненням «інтелектуалізувати» тогочасну українську літературну мову, наблизити іï словниковий склад до висококультурних західноєвропейських мов. У СУМ такі чужомовні засоби загалом супроводжуються обмежувальними ремарками заст., книжн., рідко, наприклад: Таким чином про якусь хворобу, яка нищзила би ту першорядну інституцію, нема найменшої рації говорити - тим менше єсть рації в тривоженні громадського сумління [4, с. 185], де рація - «підстава, причина» (пор.: рація, лат. - слушність, резон, підстава, причина [1, с. 364]; paція $^{2}$ - 1) розумна підстава, обгрунтування чого-небудь; мати рацію, признавати рацію, рідко - вважати кого-небудь правим у чомусь; 2) заст. вітальна промова [12, VIII, с. 459]; пол. racja - слушність, правда, істина); ...сю фразу з тих часів та й досі залюбки повторяють при кождій оказії в смиренній резигнації представники українського народу [3, с. 428], де резигнація - «покірливість» (пор.: резигнація, лат. - самопожертва, самовідданість [1, с. 369]; резигнація, книжн, заст. - цілковита покірливість долі [12, VIII, с. 487]; пол. rezygnacja - 1) відмова, зречення, заява про відставку, самоусунення з посади; 2) покірливість, примирення 3 долею; нім. die Resignation - 1) зречення, відмова; 2) розчарування, песимізм).

Значну частку серед латинізмів окресленого лексико-семантичного поля становлять мовні одиниці, що не знайшли висвітлення у спеціальних словникових джерелах, а відтак опинилася за межами чи на периферії лексичної системи сучасної літературної мови: Пишу не в осудження нинішніх політичних діячів, в добрих інтенціях котрих не хочу сумніватися, а в осудження вибраного ними політичного курсу [3, с. 260], де інтенція - «намір» (пор.: інтенція, лат. - замір, охота, гадка [10, с. 135]; інтенція, лат. - 1) намір, задум, тяжіння, 2) напруження [1, с. 181]; пол. intencja - намір, задум); Говорити про приготування наперед контингенту украӥнських дочентів $і$ професорів та помноження украӥнських катедр в теперішніх обставинах означатиме або перфідію, або непорозуміння [4, с. 81], де перфідія - «лукавство» (пор.: лат. perfídia - лукавство, лицемірство, зрадництво, підступність [7, с. 500]; пол. perfidiaпідступність, лукавство, брехливість, зрадництво; нім. die Perfidie підступність, підлість, зрадництво). Звернення до продемонстрованих слів латинської етимології зазвичай мотивувалося не браком у тодішньому українському узусі власних вербальних знаків для матеріального вираження необхідних понять абстрактного чи загальнонаукового характеру, а традицією використання чужомовних засобів у нехудожніх стилях літературної мови та, цілком можливо, наявністю корелятивних лексемвідповідників у функціонально розвинених тоді польській i німецькій мовах. У сучасному мововжитку спостерігаємо актуалізацію та соціальну реабілітацію деяких латинізмів, що в радянську добу внаслідок 
ототожнення їх із західноукраїнським мовленнєвим середовищем підпали під загальну тенденцію зниження функціонального статусу і були вилучені 3 активного словника українських мовців (інтенція, ращуія тощо).

\section{IV.Лексика на означення понять із царини літературно-} публіцистичної діяльності. Як редактор знакового в історії української громадсько-політичної думки часопису «Літературно-науковий вісник» та фундатор низки інших періодичних видань, М. Грушевський нерідко послуговується і спеціальною видавничою й літературно-публіцистичною термінологією латинського походження: Стягання співробітників $і$ праць, переписка, справлювання скриптів, мови, сліпання над коректою! Хто знає сю роботу, знає, щуо вона коштує, щзо значить проредактувати тих кілька тисяч аркушів друку! [4, с. 192], де скрипт - «рукопис» (пор.: скрипт, лат. - рукопис, лист [1, с. 526]; пол. skrypt - 1) розписка; 2) лекції, видані на правах рукопису; 3) заст. лист, документ). СУМ реєструє запозичення скрипm лише зі значенням «рукопис» i супроводжує його ремаркою заст. [12, IX, с. 321]. Те, що для ілюстрування цього латинізму в названій словниковій праці наведено лише один контекст із творчості В. Стефаника, дає підстави вважати аналізований іменник за надбання західноукраїнського регіонального зразка літературної мови кінця XIX - початку XX ст. На аналогічне трактування етимології номена скрипm натрапляємо i в «Українському стилістичному словнику» І. Огієнка, що акцентує увагу на галицькому походженні окресленої лексеми, абсолютним синонімом до якої на Великій Україні виступає слово рукопис [8, с. 367].

На окремий коментар серед репрезентантів зазначеного тематичного поля заслуговують латинські лексичні засоби, що зберігають у суспільнополітичних текстах М.Грушевського притаманні їм у мові-джерелі негативні емоційні характеристики: Але зовсім ненормальним $і$ негідним муситься назвати таку поведінку, коли група, яка форсує до Виділу своїх кандидатів, разом з тим старається понизити кандидатів противних, кидаючи на них ганебні калюмнії, та переконуючи загал про їх злу волю та нездібність управляти товариством [4, с. 175], де калюмнія - «обман, наклеп, обмова когось у пресі» (пор.: лат. călumnia - 1) брехня, неправдива скарга; викривлення істини; 2) підступи, лукавство; каверзи; підробка (фальшивка); 3) засудження та покарання за обман [7, с. 87]); Се може здаватися парадоксом. Але коли пригадати дещзо з життя покійного, воно перестане бути таким парадоксальним - принаймні в тих ревеляціях, які так рясно посипалися на голову покійного, не знаходимо ніяких конкретних даних, які б сьому противилися [3, с. 478], де ревеляція - «сенсаційне викриття» (пор.: лат. rě̀vēlo - відкривати, виявляти; розвінчувати [7, с. 598]; пол. rewelacja - 1) відкриття, сенсація, викриття; 2) признання, одкровення). Позначені внутрішньою виразністю, такі чужомовні слова вирізняються потужним прагматичним навантаженням i використовуються 
М. Грушевським для викриття негативних процесів, що відбувалися в тогочасній періодичній пресі й суспільстві загалом.

Подекуди лексичні запозичення з царини літературно-публіцистичної діяльності видозмінюють властиві їм у латинському узусі емоційноекспресивні відтінки й набувають нових виражальних можливостей. Так, наприклад, субстантив елюкубрація в мові-джерелі характеризується помірною інгерентною експресивністю (пор.: елюкубрація, лат. - результат тяжкої розумової роботи і безсонних ночей (друковані праці, статті тощо) [1, с. 160]; лат. élücŭbro - 1) працювати вночі при лампі; 2) ретельно працювати над чим-небудь, старанно обробляти [7, с. 220]), проте в одній із досліджуваних реченнєвих конструкцій відзначаємо істотне переосмислення семантики цього слова й уживання його 3 переносним, різко негативним значенням «бездарна журналістська писанина; вигадки», наприклад: Приятельська рука прислала мені число «Гражданина»(22), де якийсь пан, щзо підписав себе словом «Київянин», вириваючи фрази з моєї книжки ("Очерки истории украинского народа») $i$ додаючи до них свої вигадки $i$ здогадки, відкриває потайні наміри «украйнофілів» $i$ малюе страшні перспективи, які рисуються в разі увільнення украӥнства від репресій, що тяжать над ним у Росії. До сеї посилки вона долучила замітку, що отся стаття уважається голосом київського «Русского собрания». Ся обставина дає певне право на увагу елюкубраціям сеї статті $i$ змушує мене написати отсі рядки [2, с. 429]. Аналогічні зрушення в семантичній структурі наведеного латинізму фіксують i матеріали до словника «Українська літературна мова на Буковині в кінці XIX - на початку XX ст.» Л. Ткач (пор.: елюкубрация, ельокубрация, перен., експр. - писанина, нездарні журналістські дописи [13, с. 113]), що говорить про відтворюваність субстантиву елюкубрація в галицько-буковинському мовленнєвому просторі на зламі XIX i XX ст. не з прямим, характерним йому в латинській мові значенням, a переносним, негативно-оцінним.

\section{V.Лексика на означення понять фінансово-економічної царини.} Переважна частка мовних одиниць зазначеного лексико-семантичного поля в досліджуваний період становила спільний фонд західноукраїнського й східноукраїнського варіантів літературної мови, тому цілком закономірним $\epsilon$ те, що більшість із них увійшла до сучасного українського вжитку: eксnропріація - примусове вилучення власності органами державної влади [2, с. 365]; калькуляція - форма калькуляційного листа, у якому розраховують собівартість робіт за встановленими статтями витрат [4, с. 194]; субвенція - форма фінансової допомоги держави місцевим органам влади [3, с. 283]; субсидія - вид допомоги, що надається державою, юридичною чи приватною особою іншими особам [4, с. 184]. Наведені латинські запозичення виступають невід'ємною складовою таких жанрів публіцистичної мовотворчості М. Грушевського, як економічні огляди, звіти, замітки, де автор подає фахову оцінку конкретних подій чи фактів із фінансово-економічної царини суспільного буття. 
Водночас високу продуктивність виявляють і спеціальні терміни латинського походження, що репрезентують власне західноукраїнський лексикон кінця XIX - початку XX ст., наприклад: Векселеві довги були, але се не був «останній рятунок», вони сплачувалися постійно $і$ рати не залягали роками, ніколи не було випадку здержання пенсії урядникам... [4, с. 183], де pama - «час виплати боргових зобов'язань» (пор.: pama, лат. - 1) частина виплати (за кредитування, орендної плати тощо); 2) термін, реченець сплати [1, с. 524]; pama, заст. - термін сплати боргу, а також частина боргу, сплачена в якийсь відрізок даного строку [12, VIII, с. 453]; пол. rata - внесок); Кожний мусить оплачувати свій чинш; лише в виїмкових обставинах, коли студент дійсно не може заробити й не має звідки заплатити, йому кредитують $i$ записують на пізніший рахунок [2, с. 243], де чинш - «оплата за житло» (пор.: чини - лат. через нім. уплата за уживанє чужої річи, аренда [10, с. 324]; чинш, icm. натуральний або грошовий податок, що його платили поміщикам чи на державу в феодальній Європі [12, XI, с. 327]; пол. czynsz - 1) icm. чинш, оброк; 2) орендна плата за нерухомість; 3) квартирна плата). Розширення суспільних функцій української мови на Наддніпрянщині після 1906 р. відкрило перспективи для входження цих латинізмів у східноукраїнський комунікативний простір, а тому вже в «Російсько-українському академічному словнику» 1924-1933 рр. обидві з наведених термінолексем пропонуються як відповідники до російського аренда, причому без жодних стилістичних маркувань (пор.: аренда - 2) (арендная плата) - оренда, pama, чини [9, с. 8]). У радянську добу ці слова опинилися на периферії фінансово-економічної терміносистеми й зазнали зниження функціонального статусу, що засвідчує СУМ, у якому субстантив pama трактується як застарілий, а іменник чинш як історизм, причому значення останнього представлено лише частково - не враховано властивих йому на початку XX ст. семантичних відтінків «орендна плата; плата за житло».

VI. Лексика на означення понять зі сфери юриспруденції та судочинства. Репрезентати цього лексико-семантичного поля в доробку академіка М. Грушевського представлені доволі скромно. Незначна частка 3 окреслених запозичень фіксується україномовними академічними словниками, причому деякі з них навіть стали надбанням сучасної лексичної системи, наприклад: екзекуція - виконання судового чи адміністративного вироку про смертну кару, тілесне покарання, стягнення боргу, податку [5, с. 232]; лехітимація - визнання чи підтвердження законності якогонебудь права або повноваження; документ, який підтверджує це право або повноваження [4, с. 60]; санкція - 1) затвердження чого-небудь вищою інстанцією; визнання законності чогось; 2) заходи впливу, покарання за порушення закону [5, с. 17]. Щодо латинізмів, які на зламі XIX і XX ст. побутували в західноукраїнській юридичній царині, то ця категорія слів (чи їх лексичних форм) опинилася за межами нинішньої правничої термінології: 
Той просить допильнувати його подання, той рекурсу, там - неправне перенесення [3, с. 283], де рекурс - «скарга у вищу судову інстанцію» (пор.: рекурс, лат. - скарга вищій судовій інстанції на вирішення нижчої; рекурсувати, лат. - подавати скаргу на судовий присуд до вищого суду [1, с. 524]; пол. recurs - позовна заява у вищу інстанцію); Тої групки незалежних цивілів, щзо беруться до політичної роботи (<..>), ледве вистає на провідників [2, с. 145], де цивіл - «цивільний» (пор.: лат. cīvīlis 1) цивільний; 2) загальнокорисний; 3) ласкавий, увічливий [7, с. 106]; пол. cywil - цивільний; нім. das Zivil - 1) цивільні люди; цивільне населення; 2) цивільний одяг). Зіставний аналіз фонетичного оформлення й морфологічної будови проілюстрованих термінолексем із їх еквівалентами в латинській, польській i німецькій мовах говорить про польське посередництво в позичанні цих слів українською мовно-літературною практикою.

VII.Лексика на означення понять повсякденно-побутового xарактеру. Репрезентантами зазначеного тематичного поля в публікаціях М. Грушевського загалом слугують яскраві зразки побутового мовлення тогочасної галицької інтелігенції: вакації - період відпусток, канікули [3, с. 497]; колігація - свояцтво, зв’язки [4, с. 41]; курзор - посильний [2, с. 268]; оказія - зручна нагода, випадок [3, с. 19], наприклад: Бросквиня (персик) є не щуо інше, як культивована варіація мигдалю, але не знаю, чи оборониі генетичних зв'язків згодилися б замість смаковитого м'яса бросквини жувати иупку шкіру мигдалю, i m. ін. [2, с.125], де бросквиня «персик» (пор.: брескиня (бросква), лат. через нім. - таке овочеве дерево [10, с.48]); Мешкання в покої, призначенім на чотирьох студентів, з опалом $i$ світлом може коштувати не дорожче 7 кор. місячно, вікт-яких 15 корон [2, с. 242], де вікm - «харчування» (пор.: вікт, лат. - харчі, харчування $[1$, с. 88]). Фіксація наведених латинізмів лексикографічною практикою свідчить про їх належність до активного вжитку кінця XIX початку XX ст., однак, незважаючи на це, переважна частка таких лексем не потрапила до реєстру СУМ чи спеціальних українських довідників чужомовних слів. 3 високою вірогідністю можна припускати, що саме західноукраїнська етимологія відповідних мовних засобів стала головною причиною зниження їх функціонального статусу в сучасній українській мові.

Крім запозичень, що мають іменникове оформлення, високою частотністю в суспільно-політичній мовотворчості М.Грушевського відзначається лексико-граматичний розряд лінгвоодиниць латинського походження, що виступають носіями процесуальної, або динамічної, ознаки. Особливість таких дієслів полягає в тому, що в їх словотвірній структурі поєднуються латинські кореневі морфеми та власне українські афіксальні форманти, наприклад: Та щзо все те винесе кілька мільйонів корон, трудно надіятися, аби руська суспільність потрапила скоро абсольвувати сей 
накинений їй обов'язок і дістати право складати на інші иілі [2, с. 268], де дієслівний компонент абсольвувати (абсольв + ува $-m u)$, який походить від лат. absolvo - 1) відв'язувати; звільняти; 2) перен. звільняти, виправдовувати (звинуваченого); 3) платити, оплачувати; 4) викладати; 5) закінчувати, доводити до завершення [7, с.13], означає «звільнити, скинути з себе» (пор.: нім. absolvieren - 1) закінчувати (навчальний заклад); 2) провадити, виконувати; пол. absolwent - відпускник, випускник); ...nроф. Грушевський ургував завсіди навіть в останній час контролера, аби переводив контролю діловодства та здав справу з фінансового стану Товариства... [4, с. 187], де дієслівний елемент ургувати (ург + ува - ти), утворений від лат. urgeo - 1) напирати, утискати; підганяти, штовхати; 2) пригнічувати; мучити; 3) прилягати, межувати; 4) наполягати на чомусь, наполегливо займатися чим-небудь [7, с. 691], використовується зі значенням «квапити, підганяти» (пор.: нім. urgieren - наполегливо квапити; пол. urgować, заст. - нагадувати про термін, квапити, підганяти 3 виконанням чогось); Не хотячи, аби се звучало в моїх устах порожнім звуком, я також субскрибую отсим п'ятсот корон, платних при отворенні першої руської приватної гімназії... [2, с. 261], де дієслово субскрибувати $($ субскриб $+\boldsymbol{y} \boldsymbol{\varepsilon a}-m u)$, що спродуковане від лат. subscrībo -1$)$ робити внизу підпис; підписуватися; 2) юр. письмово підтверджувати звинувачення або позов; 3) записувати, позначати [7, с. 647], має значення «зобов'язуватися підписом, підписуватися» (пор.: нім. subscribieren - підписуватися; пол. subskrybować - підписувати). Наявність у будові цих дериватів власне українських афіксальних засобів свідчить про морфолого-словотвірну адаптацію латинських дієслівних основ до граматичних законів української мови. Як ілюструють текстові фрагменти, такі утворення на зламі XIX i $\mathrm{XX}$ ст. здебільшого обслуговували царину ділового адміністрування, громадсько-політичних відносин у суспільстві та виконували насамперед номінативну функцію. Більшість із них були надбанням західноукраїнського мовного досвіду й мали співвідносні еквіваленти в німецькій і польській мовах. Імовірно, саме цією обставиною зумовлена відсутність відповідних слів у реєстровій частині сучасних лексикографічних праць.

Отже, публіцистичний доробок М. Грушевського демонструє яскраві зразки лексичних запозичень латинської етимології, що загалом ілюструють західноукраїнську мовно-літературну традицію кінця XIX - початку XX ст. Із семантичного погляду це передусім лінгвоодиниці для номінації необхідних на той час понять із царини суспільно-політичного, освітньонаукового, фінансово-економічного, літературно-публіцистичного та юридично-правового життя, які належали до шару книжної лексики. Чимало 3 них мали давню культурно-писемну традицію використання в українській мові як репрезентанти вищих «нехудожніх» стилів, проте в радянський період, мабуть, через ототожнення з галицьким мовленнєвим середовищем, 
вони зазнали зниження функціонального статусу й були вилучені 3 активного слововжитку. У сучасному комунікативному просторі спостерігаємо соціальну реабілітацію й відновлення стилістичного потенціалу деяких із цих слів (габілітація, інгеренція, інтенція, рація тощо), однак відповідна проблема потребує окремого дослідження.

\section{Література}

1. Бойків I. Словник чужомовних слів / Бойків І., Ізюмов О., Калишевський Г., Трохименко М. - [Репринт з 2-го переробл. вид. 1955 р.]. - К. : Музей Івана Гончара ; видавнича фірма «Родовід», 1996. - 535 с.

2. Грушевський М. Твори : у 50 т. / Михайло Грушевський / ред. : П. Сохань (голов. ред.) та ін. - Львів : Світ, 2002. - Т. 1 : Серія «Суспільно-політичні твори (1894-1907)». $-592 \mathrm{c.}$

3. Грушевський М. Твори : у 50-и т. / Михайло Грушевський / ред. : П. Сохань (голов. ред.) та ін. - Львів : Світ, 2005. - Т. 2 : Серія «Суспільно-політичні твори (1907-914)». - $704 \mathrm{c.}$

4. Грушевський М. Твори : у 50-и т. / Михайло Грушевський / ред. : П. Сохань (голов. ред.) та ін. - Львів : Світ, 2005. - Т. 3 : Серія «Суспільно-політичні твори (1907 - березень 1917)». - 792 с.

5. Грушевський М. Твори : у 50-и т. / Михайло Грушевський / ред. : П. Сохань (голов. ред.) та ін. - Львів : Світ, 2007. - Т. 4 : Серія «Суспільно-політичні твори (доба Української Центральної Ради березень 1917 - квітень 1918)». - Кн. І. - 432 с.

6. Жовтобрюх М. А. Мова української періодичної преси (кінець XIX - початок XX ст.) / М. А. Жовтобрюх. - К. : Наукова думка, 1970. - 303 с.

7. Латинско-русский словарь / [сост. А. М. Малинин] ; ответ. ред. А. Н. Попов. М. : Гос. изд-во иностр. и национ. словарей, 1952. -763 с.

8. Огієнко І. Український стилістичний словник : Підручна книжка для вивчення української літературної мови / Іван Огієнко. - [2-е вид.]. - Вінніпег ; Канада, 1978. - $477 \mathrm{c}$.

9. Російсько-український академічний словник (1924-1933) [Електронний ресурс] / гол. редактори А. Кримський, С. Єфремов ; підготував електронну версію Олександер Телемко. - К. : Вид-во «К.І.С.», 2007. - 2544 с. - Режим доступу до словника : http://www.r2u.org.ua/html/krym_details.html.

10. Словар чужих слів (12.000 слів чужого походження в українській мові) / [зібрали др. Зенон Кузєля і Микола Чайковський ; зредаг. др. Зенон Кузєля]. Чернівці, 1910. - 368 с.

11. Словник іншомовних слів / [Пустовіт Л. О., Скопенко О. І., Сюта Г. М. та ін.] ; за ред. Л. О. Пустовіт. - К. : Довіра, 2000. - 1017 с.

12. Словник української мови : в 11 т. - К. : Наукова думка, 1970. - Т. І. - 799 с. ; 1971. - T. II. -550 c. ; 1972. - T. III. - 744 c. ; 1973. - T. IV. -840 c. ; 1974. T. V. -840 c. ; 1975. - T. VI. -832 c. ; 1976. - T. VII. -723 c. ; 1977. - T. VIII. 927 c. ; 1978. - T. IX. -916 c. ; 1979. - T. X. -658 c. ; 1980. - T. XI. -699 c.

13. Ткач Л. Українська літературна мова на Буковині в кінці XIX - на початку XX ст. / Людмила Ткач. - Чернівці : Рута, 2000. - Частина 1 : Матеріали до словника. $-408 \mathrm{c}$.

14. Українська мова : [енциклопедія] / ред. : В. М. Русанівський (співголова) та ін. [2-ге вид., випр. і доп.]. - К. : Вид-во «Укр. енцикл.» ім. М. П. Бажана, 2004. - 824 с. 